Bohdan Cherkes, Stanislav Myhal

\title{
IGOR SEREDYUK - AN ARTIST WHO WAS AHEAD OF TIME
}

\author{
Lviv Polytechnic National University \\ 12, Bandery Str., Lviv, 79013, Ukraine \\ tscherkes53@gmail.com,orcid.org/0000-0001-6809-956X
}

Received: 25/04/2019 /Revised: 12.05.2019/Accepted: 07.06.2019

(C) Cherkes B., Myhal S., 2019

Seredyuk Igor (1929-2016) - Ukrainian architect and designer, theorist of architecture and contemporary design, professor.

In the 70's and 80's he became one of the key figures in the theory of architecture and design, architecture and design education in Ukraine and influential figure in the education system of Central and Eastern Europe.

Igor Ivanovych Seredyuk was born in 1929 in Poland. He received his architectural education at Lviv Polytechnic Institute, having graduated from the Department of Architecture (1948-1953) and postgraduate studies (1960-1962).

He had a powerful scientific and practical influence from the scientific supervisor during postgraduate studies, the Head of the Department of Architectural Design, Professor I. Bagensky. Moreover, an overall creative, democratic atmosphere prevailed at the department. It also encouraged a young scientist.

Talent, perseverance, inclinations of the leader and exceptional desire for the best result - these qualities were noted by the colleagues of I. Seredyuk. The traditions of Lviv School of Architecture and Design in the sphere of formation of the subject world and the environment of human activity had a significant influence on the formation of his professional outlook and creative personality.

In the period of post-war recovery of Ukrainian economy, there were radical changes in all social sectors, the transformation of traditional industrial paradigms, and changes in value orientations. Design activity became an integral part in terms of social and cultural dimension. In the context of pan-European trends, in 1959 there was a training of specialists by "Interior and Furniture Design" specialty at Lviv Polytechnic, and in 1960 "Architecture, Furniture, Interior". Designing activity was shaped and developed as a socially and culturally necessary phenomenon, caused by socio-economic and cultural-ideological development of society, social production and consumption.

I. Seredyuk was one of the first to evaluate the role and importance of design in shaping the human environment and actively engaged in practical and theoretical solutions to this important problem. At the beginning of the 1960s, the Student Design Bureau (SDB) of Lviv Polytechnic developed a program of built-in transformed equipment for student dormitories. A piece of equipment of this program (introduced by I. Seredyuk) was exhibited at the Exhibition Achievements of National Economy in Moscow in 1962 and had a silver medal award. This program has become a model for the conceptual approach to the formation of economic and social housing, which would provide on this basis the minimum needs of the consumer. In 1964 Igor Seredyuk developed upholstered chairs for the assembly hall of the first building of Lviv Polytechnic. At the beginning of the 70's he and S. Migal took part in the development of a program of furniture and equipment for educational institutions of the Ministry of Education of Ukraine, which was soon implemented.

In 1963, I. Seredyuk defended his thesis "Architectural and structural prerequisites of designing furniture of modern apartments" and received a scientific degree of Candidate of Architecture. 
In 1964 he underwent a scientific internship in France. Personal meetings with Le Corbusier in his workshop, permission to use the library, archive and communication within the workshop expanded the range of professional interests of I. Seredyuk. Attending cycles of lectures at the Ministry of Construction and at the Science and Technology Center in Paris, read by V. Bodiansky, J. Candilis, M. Lads, B. Lassou, J. Pruve, J. Schein, as well as personal contacts, exchange of articles, monographs and scientific ideas with M. Benz, A. Baie, B. Barkin, R. Bosil, K. Dvorzak, U. Eko, G. Lavrik, G. Minervin, A. Mol, J. Friedman, I. Strautmanis, V. Kurt - Umerov, O. Shvidkovsky contributed to the formation of critical analytical approaches to architecture and alternative views on its theoretical problems, broad understanding of the environment as a complex multifactorial and mobile phenomenon, the study of patterns of which requires the usage of interdisciplinary approaches. The main theoretical results, combined into a corresponding system of psychological analysis of the environment, are the consequence and further development of the ideas generated in the works of V. Dakhn, M. Demin, G. Lavryk, V. Mironenko, I. Fomin, A. Yablonsky. The works of these authors actually laid the foundations for the development of national science in the design of the architectural environment of the late XXth century.

In the 1965-67s I. Seredyuk worked as a Head of the Department of Building Materials at the Royal Technical University in Cambodia. Along with his teaching activities, he designed several villas for the university directorate and they were built. For his successful national training and cultural development, he obtained an award of the Order of Commander Cambodia by the People's Republic of Sihanouk.

I. Seredyuk was one of the active organizers of architectural and design education in Ukraine. In 1971 the Department of Architecture was restored at Lviv Polytechnic Institute (since 2001 - the Institute of Architecture), the dean of which was I. Seredyuk, which contributed to the qualitative evolution of architectural education in Lviv. The structure of the institute included the following departments: "Architectural Design" (the head of the department is Prof. I. Seredyuk); "Urban Planning" (Head of the Department - Prof. A. Rudnytsky); Architectural Structures (Head of the Department - Assoc. Prof. Y. Shvets); "Drawing and Painting" (Head of the Department - Assoc. Prof. R. Lypka, since 2003 Department of "Design and Fundamentals of Architecture", Head of the Department - Prof. B. Cherkes). In 1992, there was the Department "Reconstruction and Restoration of Architectural Complexes" (now "Restoration of Architectural and Artistic Heritage", headed by Professor M. Bevz).

There is a democratic atmosphere at the Department. The staff of teachers and students was the only family for which the sole purpose and sole criterion was Architecture. The School of Architecture is becoming a powerful "locomotive", which forms and produces talented specialists. It not only generates new ideas and design methods, but also pioneers fundamental changes in the pedagogy.

In the 60-70s I. Seredyuk took part in the work of the state boards of the Ministry of Industrial Policy of Ukraine on the assessment of the quality of household goods and consumer goods. The experience gained is used in the program materials of "Lviv Integrated Product Quality Management System (IPQMS)", which is implemented in its territory on the recommendation of the USSR leadership. It is also worth noting that during this period Lviv became one of the centers of Central and Eastern Europe in the field of industrial design. The serial bus "Tourist" (designed by Ya. Trach, R. Mirensky) at the World Exhibition in Belgium (Brussels, 1958) was marked with a gold medal, while the buses "Ukraine - 67" and "Ukraine - 69" (V. Pyvovarov, P. Chepel) at the 18th and 19th international weeks in France (Nice, 1967, 1969) received a silver medal and a Grand Prix for high performance and comfort. The first domestic TV models of the Ist - IVth generation were being developed at the SDB of Lviv Television Plant: Lviv, Verkhovyna, Vognyk, Electron (A. Glushko, B. Bratyko, M. Zubchenko). SDB of Lviv Forestry developed conceptual furniture (S. Migal) for study rooms and laboratories, which had a gold medal award at the Exhibition of Achievements of National Economy in Moscow (1972, 1975). With the opening of Lviv House of Models in 1954, costume collections (S. Semenko, L. Mazur, A. Shevchenko) amazed visitors and juries of exhibitions of fairs in Tokyo, Marseille, Paris, New York, Moscow, Warsaw, and Budapest with the creative imagination.

As an ideologist and a bright representative of Lviv School of Design, the so-called "star generation" of Ukrainian design in the 60-80s, I. Seredyuk advocates the necessity to transform the methodology of 
designer training, to integrate all types of plastic art into the architectural environment. "Functionalism, as I. Seredyuk noted, which for decades has unified, standardized and unified our environment - architecture, urban planning, design, has come into sharp contradictions with real human needs and opportunities. A person no longer wants to live in the same residential buildings, work and study in the same interiors, walk the streets with monotonous construction ... The central aspects of creativity - cultural, psychophysical and semantic ... The modern creative process is complex, systematic".

In 1977-1987 I. Seredyuk - Rector of Lviv State Institute of Applied and Decorative Arts (LSIADA, since 2004 - Lviv National Academy of Arts). The training of artists in decorative and applied arts at the Institute was conditioned by the traditional art and craft model by type of the Bauhaus School of Architecture and Art (19191933) on the basis of combination of education and craft. Handwork with materials was considered a perfect and irreplaceable school of artistic skill and development of creative abilities. The ideology of decorativeism largely dominated the institute.

In the period of post-industrial society formation, radicalism in architecture and design, transformation of industrial paradigms into new post-industrial ones, different attitudes towards creativity, traditional principles and norms of design were formed. The foundations of these searches were laid by prominent designers - educators of the Ulm High School of Formation (1953-1967) by M. Bill, T. Maldonado, and H. Gugelot. Their aim of creativity was in modeling in the social space of new reality in the context of combination of scientific and technological progress and aesthetics.

The idea of projection, formation of culture of project interdisciplinary thinking and culture of artistic education served as the basis of fundamentals of the training of specialists' methodology by Professor I. Seredyuk. To accomplish these tasks, together with the Departments of "Interior and Furniture Design" (S. Migal, Head of the Department) and "Design of Clothing" (T. Kuzminska, Head of the Department), he created the qualification characteristics and models of specialists for acquiring new knowledge, skills and capabilities. A number of disciplines have been introduced into the curricula with a focus on a broad integration with manufacturing. The subordination of all academic disciplines to the main one - design, promotes qualitative preparation of specialists for the conditions of real practical activity, as well as tangible practical usefulness of the obtained knowledge. The theory and practice of design, combined with the modern production and technological sphere, became one of the initial models for the introduction of new ideas, conceptual and contextual approaches. It was also facilitated by the experimental and creative associations of teachers and students, created in the research sector of the Institute: "Prestige" in the field of costume design, "Spectrum" - environmental design and SDB in furniture design. The structure of the Association "Prestige" (supervised by O. Korovytsky) included all sewing schools in Lviv, which implemented creative ideas of students of the Institute. The design of furniture - the program of furniture "Universal" (B.Kurlishchuk, S.Migal) for Production Association (PA) "Lvivderev", due to which nine experimental sets of furniture were exhibited at the regional exhibition (Lviv, 1981) - provoked positive public resonance. In 1982-83, a series of chairs and sets of cabinet furniture "Vatra", "Crystal" and "Systema" (co-authored with V. Pavlov and O.Tazalov) were developed under this program. They were presented at the IVth All-Union contest "Furniture-83" in Moscow and honored with juries I, II and special prizes respectively. The preparation of artists of decorative art in interior and furniture, modeling of clothes was carried out with the implementation of complex coursework and diploma works on real subjects and taking into account their further work in the conditions of industrial production. These are numerous interior design of public buildings, playgrounds in Lviv, socio-cultural environment in the National Historical and Cultural Reserve "Naguevychi" "Pathways of Ivan Franko": etc.

The project conceptualism of interior and furniture design, artistic modeling of clothing, consumer goods in the field of innovation and the search for national identity became a specific project form of knowledge of Lviv School. They are an example of new thinking and a reflection of globalization and national aspects of environmental design within the walls of LSIADA. Reviews of diploma works of students of architectural and artistic universities in Central and Eastern Europe serve as a proof. Scientific and 
methodological council for aesthetic education and art education at the Academy of Arts of the USSR and the Ministry of Education of the USSR by annual materials of All-Union exhibitions of diploma works of students of art universities in Vilnius (1978), Kiev (1979), St. Petersburg (1980), Baku (1981), Tbilisi (1984), highly appreciated new searches and professional level of completion of diploma projects of interior design, furniture and clothing of Lviv School. In these forums Professor I. Seredyuk acted as a representative of the Ukrainian School of Architecture and Design, and the rector of the National Academy of Fine Arts and Architecture (Kyiv), People's Artist of Ukraine, Professor of Fine Arts Oleksandr Lopukhov. Meetings with leading artists, academicians of the Academy of Arts, leaders of the Republics, where forums were held, facilitated the establishment of organizational and creative contacts.

The first persons of Azerbaijan (G. Aliyev) and Georgia (A. Shevardnadze) separately received the reception of Lviv delegation, as Lviv citizens were preparing national personnel for these Republics. LSIADA is on a par with the Lithuanian and Latvian Academies of Arts, Moscow Art and Industrial Academy named after S. G. Stroganov (Russia). It was facilitated by the great work of Professor I. Seredyuk in the scientific and pedagogical field and his high regard.

During the principalship of I. Seredyuk, the social and physical infrastructure of the LSIADA was enhanced. A new experimental and laboratory building of the Institute (architect M. Vendzylovych) and a food processing plant (architect A. Konsulov) were under construction. The design and equipment of these buildings by their employees and pupils was carried out in accordance with Lviv tradition of constructing and designing educational buildings, initiated by Rector of Lviv Polytechnic Yu. Zakharievych.

In 1982-1985 he became a UNESCO expert and head of the Ministry of Higher and Secondary Specialized Education of Ukraine on long-term, cross-national research in the topic No. 11 "New Technologies in Education". In 1992 he became a Ukrainian correspondent from the international magazine L'Arca (Italy, Milan).

In 1988-1999 I. Seredyuk - Professor of the Department of Architectural Design of Lviv Polytechnic. In 1999 Professor I. Seredyuk celebrated his 70th birthday at the Architecture Department of Lviv Polytechnic and moved to live in Prague with his daughter, who worked and lived there. I. Seredyuk died at the age of 87 in Prague, where he lived in his recent years.

Professor Igor Seredyuk is the author of about 80 articles, 8 of which were published in foreign publications (France, Russia, Italy, Cambodia), 3 monographs "Culture of your apartment" (1970), "Perception of the urban environment" (1979), "Urban environment and optimization of human activity" (1987, co-authored). The latest monograph gave rise to school of psychophysical analysis in architecture, recognized by the Institute of Social Psychology of the University of Strasbourg (Prof. A. Mol). The published materials on this issue have received positive reviews in the Czech Republic, Germany, France, Italy.

Public speeches, lectures, numerous articles by Professor Igor S. Seredyuk made a significant impact on the development of project ideology and practice.

\section{References}

[1] Mygal S. P. Lviv Design School: formation, problems, prospects. Dialogue of cultures: Ukraine in a global context. Art education. Coll. Of Scientif. Works. Lviv: Svit, 2000. P. 387-399.

[2] Mygal S. P. Design. Lviv School. Lviv: Papuga, 2004. P. 9-30.

[3] Proskuryakov V.I. Anthology of Lviv Architectural School. Creative work and pedagogical activity of the teachers of the Department of Architecture in the 60-80's of the XXth century / V. I. Proskuryakov, O. S. Khrin // Journal "Architecture"of Lviv Polytechnic National University. Lviv: Publishing House of Lviv Polytechnic National University, 2004. No. 505. P. 397- 399.

[4] Lviv Polytechnic National University. Institute of Architecture / comp. by B. S. Cherkes, V. I. Proskuryakov, G. P. Petryshyn. Lviv: Publishing House of Lviv Polytechnic, 2012. P. 92. 


\section{ІГОР СЕРЕДЮК-МИТЕЦЬ, ЩО ВИПЕРЕДЖАВ ЧАС} nрофесор.

Ігор Середюк (1929-2016) - украйнський архітектор і дизайнер, теоретик архітектури та сучасного дизайну,

У 70-х та 80-х роках став однією з ключових фігур в теорії архітектури та дизайну, архітектурно-дизайнерській освіті в Україні та впливовою постаттю в системі освіти країн Центральної і Східної Свропи.

Ігор Іванович Середюк народився в 1929 р. у Польщі. Архітектурну освіту отримав у Львівському політехнічному інституті, закінчивши архітектурний факультет (1948-1953) та аспірантуру (1960-1962).

Потужний науково-практичний заряд він отримує від наукового керівника навчання в аспірантурі, звідувача кафедри архітектурного проектування, професора І. Багенського. Цьому сприяла також загальна творча, демократична атмосфера, яка панувала на кафедрі.

Обдарованість, завзятість, задатки лідера та виняткове прагнення до найкращого результату - иі якості відмічали колеги І. Середюка. Значний вплив на формування та становлення його професійного світогляду $і$ творчої індивідуальності мали традииї Львівської архітектурно-дизайнерської иколи у сфері формування предметного світу та середовища життєдіяльності людини.

У період стиснених умов післявоєнного відновлення господарства Украӥни відбуваються радикальні зміни усіх суспільних галузей, трансформація традиційних індустріальних парадигм і зміни иіннісних орієнтирів. Невідмінним компонентом культури суспільства стає дизайнерська діяльність. В контексті загальноєвропейських тендениій у 1959 рой у Львівській політехніці відкривають підготовку фахівиів за спеціальністю «Проектування інтер'єру та меблів», а 1960 - «Архітектура, меблі, інтер'єр». Дизайнерська діяльність формується та розвивається як сочіально і культурно необхідне явище, зумовлене соціально-економічним $і$ культурно-ідеологічним розвитком суспільства, громадського виробництва і споживання.

I. Середюк був одним із перших, хто оцінив роль $і$ значення дизайну у формуванні середовища життєдіяльності людини та активно підключився до практичного і теоретичного розв'язання иієї важливої проблеми. На початку 60-х років СПКБ Львівської політехніки розробляє програму вбудованого трасформованого обладнання для житлових комірок студентських гуртожитків. Фрагмент обладнання цієї програми (автор I. Середюк) у 1962 р. експоновано на Виставиі досягнень народного господарства у Москві й відзначено срібною медаллю. Ця програма стала моделлю для концептуального підходу до формування економічної та сочіальної житлової комірки, яка б забезпечувала мінімально необхідні потреби споживача. В 1964 р. Ігор Середюк для актової зали Першого навчального корпусу Львівської політехніки розробляє крісла-пюпітри. На початку 70-х років бере участь спільно з С. Мигалем у розробленні програми меблів і обладнання для навчальних закладів Міністерства освіти Украӥни, яку впроваджено в життя.

У 1963 рочі I. Середюк захищає дисертаџійну роботу на тему «Архітектурно-конструктивні передумови проектування меблів сучасних квартир» і отримує науковий ступінь кандидата архітектури.

У 1964 роиі проходить наукове стажування у Франиії. Особисті зустрічі із Ле Корбюзьє в його майстерні, дозвіл на користування бібліотекою, архівом та спілкування з працівниками майстерні розиирили діапазон професійних поглядів I. Середюка. Відвідування цииклів лекиій в Міністерстві будівництва та в Науково-технічному центрі будівництва в Парижі, які читали В. Бодянський, Ж. Канділіс, М. Ледс, Б. Ляссю, Ж. Пруве, Й. Шайн, а також особисті контакти, обмін статтями, монографіями та науковими ідеями з М. Бензе, А. Байі, Б. Бархіним, Р. Босілом, К. Дворжаком, У. Еко, Г. Лавриком, Г. Мінервіним, А. Молем, Й. Фрідманом, І. Страутманісом, В. Курт-Умеровим, О. Швидковським сприяли формуванню критичних аналітичних підходів до архітектури та альтернативних поглядів на ї̈ теоретичні проблеми, широкому розумінню середовища як складного багатофакторного та мобільного явища, вивчення закономірностей якого потребує застосування міждисииплінарних підходів. Основні теоретичні результати, об'єднані у відповідну систему психологічного аналізу середовища, є наслідком та подальшим розвитком ідей, генерованих у прачях В. Дахна, М. Дьоміна, Г. Лаврика, В. Мироненка, І. Фоміна, А. Яблонського. Праиями иих авторів закладено фактично основи розвитку національної науки в дизайні архітектурного середовища кінця ХХ ст.

У 1965-1967-х роках I. Середюк прачював завідувачем кафедри будівельних матеріалів Королівського технічного університету в Камбоджі. Паралельно із викладацькою діяльністю він спроектував декілька вілл для дирекціі університету, які було споруджено. За успішну підготовку національних кадрів та розвиток культури нагороджений королем Камбоджі Народомом Сіануком орденом Командора Камбоджі.

I. Середюк був одним із активних організаторів архітектурно-дизайнерської освіти в Украйні. У 1971 році у Львівській політехніџі відновлюється архітектурний факультет (з 2001 р. - Інститут архітектури), деканом якого стає I. Середюк, щу сприяло якісній еволюиії архітектурної освіти у Львові. В структуру факультету/інституту входять кафедри: архітектурного проектування (зав. кафедри - проф. І. Середюк); містобудування (зав. кафедри - проф. А. Рудницький); архітектурних конструкиій (зав. кафедри - дои. Я. Швець); рисунку та живопису (зав. кафедри - дои. Р. Липка, з 2003 р. - кафедра дизайну та основ архітектури, зав. каф. проф. Б. Черкес). 31992 року на факультеті функціонує організована і очолювана А. Рудницьким кафедра реконструкиії та реставрації архітектурних комплексів (тепер реставрації архітектурної і мистецької спадщини, зав. кафедри - проф. М. Бевз). 
На факультеті сформувалося демократичне середовище, де колектив викладачів і студентів був родиною, для якої єдиною метою і єдиним критерієм була архітектура. Архітектурна школа стає потужним «локомотивом», який формує і випускає талановитих спеціалістів. Вона стає не тільки генератором нових ідей та методів проектування, але також піонером кардинальних зрушень у самій педагогіиі.

У 60-70-х роках I. Середюк бере участь у роботі державних комісій Міністерства промполітики України 3 оцінювання якості побутових предметів та товарів народного споживання. Набутий досвід використовують у програмних матеріалах «Львівської комплексної системи управління якістю продукції (КСУяП)», яка за рекомендацією керівництва СРСР впроваджується в життя на його теренах. Варто відмітити також, щзо в цей період Львів стає одним із иентрів Центральної та Східної Свропи в галузі промислового дизайну. Серійний автобус «Турист» (диз. Я. Трач, Р. Миренський) на Всесвітній виставиі у Бельгії (Брюсель, 1958 р.) відзначають золотою медаллю, а автобуси «Україна-67» та «Україна-69» (В. Пивоваров, П. Чепель) на 18 і 19 міжнародних тижнях у Франиії (Ніциа, 1967, 1969) отримують срібну медаль та «Гран-прі» за високі експлуатаційні якості та комфортабельність. У СКБ Львівського телевізійного заводу розробляють перші вітчизняні моделі телевізорів I-IV покоління: «Львів», «Верховина», «Вогник», «Електрон» (А. Глушко, Б. Братейко, М. Зубченко). В СКБ Львівської лісотехніки виготовляють концептуальні меблі (С. Мигаль) для навчальних кабінетів та лабораторій, які на Виставијі досягнень народного господарства у Москві (1972, 1975) відзначено золотими медалями. 3 відкриттям у 1954 році Львівського будинку моделей, колекції костюмів (С. Семенко, Л. Мазур, А. Шевченко) дивують творчою фантазією відвідувачів та журі виставок - ярмарок у Токіо, Марселі, Парижі, НьюЙорку, Москві, Варшаві, Будапешті.

Будучи ідеологом та яскравим представником Львівської школи дизайну, так званого «зіркового покоління» українського дизайну 60-80-х років, І. Середюк виступає за необхідність трансформації методології підготовки дизайнера, інтеграцію в дизайні архітектурного середовища всіх видів пластичного мистеитва. «Функиіоналізм, - як зазначав I. Середюк, котрий десятиріччями уніфікував, стандартизував та уніформував наше оточення - архітектуру, містобудування, дизайн, вступив у гострі протиріччя з дійсними людськими потребами та можливостями. Людина не бажає більще жити в одинакових житлових будинках, працювати та вчитися в одинакових інтер'єрах, ходити вулицями з монотонною забудовою... Центральні аспекти творчості - культурологічні, психофізичні та семантичні... Сучасний творчий проиес має комплексний, системний характер”.

У 1977-1987 роках I. Середюк - ректор Львівського державного інституту прикладного $і$ декоративного мистецтва (ЛДIПДМ, з 2004 - Львівська національна академія мистеитв). Підготовку художників декоративного та ужиткового мистецтва в інституті обумовлювала традиџйна художньо-реміснича модель за типом архітектурнохудожньої школи Баугауза (1919-1933) на основі поєднання навчання і ремесла. Ручну працю з матеріалами вважали досконалою і незамінною школою художньої майстерності й розвитку творчих здібностей. Ідеологія декоративізму значною мірою домінувала в інституті.

У період становлення постіндустріального суспільства, радикалізму в архітектурі та дизайні, трансформації індустріальних парадигм у нові постіндустріальні, формується інше ставлення до творчості, традиційних принципів $i$ норм проектування. Фундамент ичи пошуків закладено видатними дизайнерами-педагогами Вищої школи формотворення в Ульмі (1953-1967) М. Біллем, Т. Мальдонадо, Х. Гугелотом. Вони бачили мету творчості в моделюванні у сочіальному просторі нової реальності в контексті поєднання науково-технічного прогресу та естетики.

Професор І. Середюк в основу методології підготовки спеціалістів закладає ідею проектності, формування культури проектного міждисииплінарного мислення і культури художнього образотворення. Для реалізації ичих завдань, він спільно з кафедрами проектування інтер'єрів та меблів (зав. кафедри С. Мигаль) і моделювання одягу (зав. кафедри Т. Кузьмінська) створив кваліфікаційні характеристики і моделі спеціалістів для набування ними нових знань, вмінь та навичок. До навчальних планів введено низку дисциилін з акцентом на иироку інтеграцію з виробництвом. Супідрядність усіх навчальних дисциплін головній - проектуванню, сприяє якісній підготовці фахівців до умов реальної практичної діяльності, а також відчутної практичної корисності отриманих знань. Теорія і практика дизайну, в поєднанні з сучасною виробничо-технологічною сферою, стає однією з вихідних моделей для впровадження нових ідей, концептуальноконтекстуальних підходів. Цьому сприяли також створені при науково-дослідному секторі інституту експериментальнотворчі об'єднання викладачів і студенів: «Престиж» у сфері дизайну костюма, «Спектр» - дизайну середовища та СКБ із дизайну меблів. У структуру об’єднання «Престиж» (кер. О. Коровицький) входили усі швейні училища Львова, які реалізовували творчі ідеї студентів інституту. Позитивний резонанс громадськості викликав дизайн меблів - програма меблів «Універсал» (Б. Курліщук, С. Мигаль) для ВО «Львівдерев», згідно з якою дев'ять експериментальних наборів меблів експоновано на обласній виставиі (Львів, 1981). У 1982-1983 рр. за иією програмою розроблено серію стільиів і комплекти корпусних меблів «Ватра», «Кристал» $i$ «Система» (у співавторстві з В. Павловим і О. Тазаловим), які представлено на IV Всесоюзному конкурсі «Меблі-83» у Москві і відзначено журі I, II та спеціальними преміями відповідно. Підготовка художників декоративного мистецтвва щодо інтер'єру і меблів, моделювання одягу здійснюється з виконанням комплексних курсових і дипломних робіт з реальної тематики і з врахуванням їх подальшої роботи в умовах промислового виробництва. Це численні розробки інтер'єрів громадських споруд, дитячих майданчиків у Львові, соиіокультурне середовище в Національному історико-культурному заповіднику «Нагуєвичі»-«Стежки-дороги Івана Франка» тощо.

Проектна концептуалістика дизайну інтер'єру та меблів, художнього моделювання одягу, предметів народного споживання у річищі інновацій та пошуків національної ідентичності стає специфічною проектною формою пізнання Львівської школи. Вони є прикладом нового мислення і віддзеркаленням глобалізаційних і національних аспектів розвитку 
дизайну середовища в стінах ЛДІПДМ. Про ие свідчать огляди дипломних робіт студентів архітектурно-художніх вишів країн Центральної і Східної Свропи. Науково-методична рада з естетичного виховання і художньої освіти при Академії мистецтв СРСР та Мінвишу СРСР за щорічними матеріалами всесоюзних виставок дипломних робіт студентів художніх вишів у Вільнюсі (1978), Києві (1979), Санкт-Петербурзі (1980), Баку (1981), Тбілісі (1984) високо оцінювала нові пошуки та професійний рівень виконання дипломних проектів дизайну інтер'єру, меблів та одягу Львівської иколи. На цих форумах професор I. Середюк виступає вже не як представник украӥнської архітектурно-дизайнерської иколи, а ректор Національної академії образотворчого мистеитва і архітектури (м. Київ), Народний художник України, професор Олександр Лопухов - образотворчого мистеитва. Зустрічі з провідними митиями, академіками Академії мистецтв, керівниками республік, де проводились форуми, сприяли налагодженню організачійних і творчих контактів.

Периі особи Азербайджану - Г. Алієв та Грузії-А. Шеварднадзе окремо приймали Львівську делегацію, оскільки львів'яни готували національні кадри для йих республік. ЛДІПДМ стає в один ряд з Литовською і Латвійською академіями мистеитв, МДХПУ ім. С. Г. Строганова (Росія). Цьому сприяла велика праия професора І. Середюка на науковопедагогічній ниві та його високий авторитет.

У період ректорства I. Середюка укріплюється сочіальна та матеріально-технічна база ЛДIПДМ. Будується новий експериментально-лабораторний корпус інституту (арх. М. Вендзилович) та комбінат харчування (арх. А. Консулов). Проектування і обладнання иих корпусів його працівниками та вихованиями виконують згідно з львівською традицією зі спорудження та оформлення навчальних корпусів, започаткованої ще ректором Львівської політехніки Ю. Захарісвичем.

У 1982-1985 рр. він став експертом ЮНЕСКО та керівником від Міністерства вищої та середньої спеиіалізованої освіти України з багаторічних, міжнаціональних досліджень за темою № 11 «Нові технології в освіті». У 1992 р. стає кореспондентом від Украӥни міжнародного журналу «L'Arса» (Італія, Мілан).

У 1988-1999 рр. I. Середюк - професор кафедри архітектурного проектування Львівської політехніки. У 1999 р. професор I. Середюк відзначає на архітектурному факультеті Львівської політехніки своє 70-річчя та переїжджає жити у Прагу до своєї доньки, яка там праџювала і жила. Відійшов у вічність I. Середюк на 87 рочі життя у Празі, де жив останні роки.

Професор Ігор Середюк - автор близько 80 статей. 3 них вісім статей у зарубіжних виданнях (Франція, Росія, Італія, Камбоджа), три монографій «Культура вамей квартиры» (1970), «Восприятие городской среды» (1979), «Городская среда и оптимизация деятельности человека» (1987, у співавторстві). Остання монографія закладає основи школи психофізичного аналізу в архітектурі, щьо визнано інститутом соиіальної психологї Страсбургського університету (проф. А. Моль). Опубліковані матеріали з цієї проблеми отримали позитивні рецензї у Чехії, Німеччині, Франиїі, Італії.

Публічні виступи, лекиії, численні статті професора Ігора Івановича Середюка значно вплинули на розвиток проектної ідеологї̈ та практики. 